\title{
Investigative Analysis on The Properties of Concrete Replacing Fine Aggregate with Bottom ASH and Quarry Dust
}

\author{
${ }^{1} \mathrm{D}$. R. Sasirekha, ${ }^{2} \mathrm{~S}$. Thejaswini
}

${ }^{1} \mathrm{M}$. Tech Student, Civil Engineering, PVKK Institute of Technology, Anantapur, Andhra Pradesh, India

${ }^{2}$ Assistant Professor, M. Tech, Department of Civil Engineering, PVKK Institute of Technology, Anantapur, Andhra Pradesh, India

\section{ABSTRACT}

In present condition to full-fill the demand of sustainable construction, concrete made with different materials is the best choice for the construction industry. Generally, we use materials which are required for conventional concrete and addition to those we replace the low-cost materials such as bottom ash in this project we replace the coal bottom ash \& quarry dust to the fine aggregate by variable percentages. Coal bottom ash is the by-product of coal combustion. The rock detritus filled in the fishers of coal become separator from the coal during pulverization. In the furnace, carbon, other combustible matter burns, \& the non-combustible matter result in coal ash. The coal ash collector from the electro static precipitators is called fly ash. coal bottom ash constitutes about $20 \%$ of coal ash and the result is fly ash. The perfect substitute for reverse sand is quarry dust it is the one of the ingredients in manufacture of concrete the crusher dust is known as quarry dust can be used as alternative material to the river sand. quarry dust possesses similar properties as that of river sand, hence accepted as a building material. The aggregate replaced with concrete in various percentages as both BA and QD (10\%,20\%\&30\%). All replacements where done to the m30 grade of concrete. the concrete has been replaced by coal bottom ash accordingly to the percentage, and fine aggregate has been replaced by quarry dust in percentage. concrete mixtures where produced, tested \& compared in terms of compressive strength, tensile, flexural strength are evaluated. The curing of cubes, cylinders, \& beams is 7days 28days \& 90days.

Keywords : Raspberry pi, USB camera, motor driver, motor, LCD display, road side speed sign controlling.

\section{INTRODUCTION}

Concrete is the utmost important material for the erection of high rise buildings and several infrastructures. Infrastructure development in such areas predominantly in developing countries like India is more. Concrete is a blend of cement, fine aggregate, coarse aggregate and water and river sand is the key raw material used as fine aggregate in the manufacture of concrete. The natural sources of river sand are getting exhausted steadily. The need for the safeguarding of the natural environment and the ban on excavating in some areas is further provoking the problem of accessibility of river sand.

At present-day, the structural industry is afflicted with the paucity of this crucial constituent material of concrete. Hence, in the present situations of limited sources of river sand and success in infrastructure development, it becomes necessary and more substantial to find out its standby material in concrete. Coal bottom ash is a coarse rough and fireresistant by-product from coal burning furnaces. It is poised of mainly silica, alumina and iron with small 
amounts of calcium, magnesium sulphate, etc. The appearance and particle size distribution of coal bottom ash is similar to that of river sand. These properties of coal bottom ash make it attractive to be used as fine aggregate in the production of concrete.

Various industries produce numerous solid waste materials. The disposal of these solid waste materials is an environment hazard for the surrounding living beings. Cachimetal. (2014)observed that be cause of increasing environmental concern sand sustainable issues, the utilization of solid waste materials is the need of the hour. Based on the research reports some solid waste materials such as fly ash, silica fume, grounded blast furnace slag etc have been put in use in manufacturing of either cement or concrete. In India, about $67 \%$ of electricity requirements are fulfilled by the coal fired thermal power plants (CEA, 2012). Electricity demand in the country is increasing every year. At present, the country is facing average energy shortage of $6.7 \%$ at national level but the southern part of the country experience $26.7 \%$ energy shortage (CEA, 2012).

\section{COAL BOTTOM ASH}

Coal bottom ash is the by-product of coal combustion. The rock detritus filled in the fissures of coal become separated from the coal during pulverization. In the furnace, carbon, other combustible matter burns, and the non-combustible matter result in coal ash. Swirling air carries the ash particles out of hot zone where it cools down. The boiler flue gas carries away the finer and lighter particles of coal ash. The boiler flue gases pass through the electrostatic precipitators before reaching the environment. In the electrostatic precipitators, coal ash particles are extracted from the boiler flue gases. The coal ash collected from the electrostatic precipitators is called fly ash. Fly ash constitutes about $80 \%$ of coal ash. During the combustion process some particles of the coal ash accumulate on the furnace walls and steam pipes in the furnace and form clinkers. These clinkers build up and fall to the bottom of furnace. In addition, the coarser particles, which are too heavy to remain in suspension with the flue gases, settle down at the base of the furnace. The ash collected at the bottom of furnace is called coal bottom ash. Coal bottom ash constitutes about $20 \%$ of coal ash and the rest is fly ash.

At present, India is the third biggest purchaser of coal. Around 524 million tons of coal is singed in coal let go warm power every year (CEA, 2014). They are the primary wellspring of creation of coal slag. Indian coals have higher slag content up to $45 \%$ contingent on the wellspring of the coal and result in vast volumes of coal fiery debris (CEA, 2014). According to Central Electricity Authority, India, report (CEA, 2014), 143 no coal let go warm power plants with introduced limit of 133381 MW created around 173 million tons of coal fiery debris yearly. With the limit expansion of $22282 \mathrm{MW}$ before the finish of 2017, the generation of coal Ash is assessed to 220 million tons for every year. Fig. 1.1 shows the production of coal ash at coal fired thermal power plant.

\section{Physical Properties of Coal Bottom Ash}

The coal bottom ash is mainly due to the presence of rock detritus in the fissures of the coal seams. The variability in the rock detritus from one source to another therefore causes variation in the properties of coal bottom ash as well. The factors that affect the properties of coal bottom ash are:-

- Degree of pulverization of coal

- Firing temperature in the furnace

- Type of furnace

Coal Bottom Ash has rakish, sporadic, permeable and harsh surface finished particles. The particles of Coal 
Bottom Ash extend from fine sand to fine rock. Coal Bottom Ash debris has appearance and molecule measure appropriation like that of waterway sand. Coal Bottom Ash is generally a very much reviewed material despite the fact that varieties in molecule measure dissemination can be experienced from a similar power plant. Particles of Coal Bottom Ash have interlocking attributes. Coal Bottom Ash remains is lighter and more weak when contrasted with normal stream sand. The particular gravity of coal base Ash fluctuates from 1.2 to 2.47 contingent on the source and sort of coal. Coal Bottom Ash debris with low particular gravity has a permeable surface that promptly corrupts under stacking or compaction. Coal Bottom Ash remains gotten from high sulfur coal and low rank coal is not exceptionally permeable and is very thick (www.caer.uky.edu). The distributed writing demonstrates wide variety in physical properties of Coal Bottom Ash. Table1 shows the physical properties of coal bottom ash reported in the published literature.

Table 1. Physical properties of coal bottom ash

\begin{tabular}{|l|l|l|l|l|l|l|l|}
\hline $\begin{array}{l}\text { Physical } \\
\text { properties }\end{array}$ & $\begin{array}{l}\text { Yuksel } \\
\text { \&Genc } \\
(2007)\end{array}$ & $\begin{array}{l}\text { Kouand } \\
\text { Poon } \\
(2009)\end{array}$ & $\begin{array}{l}\text { Bai et al. } \\
(2005)\end{array}$ & $\begin{array}{l}\text { Kim\& } \\
\text { Lee } \\
(2011)\end{array}$ & $\begin{array}{l}\text { Naik } \\
\text { et al. } \\
(2007)\end{array}$ & $\begin{array}{l}\text { Ghafoori } \\
\text { \&Bucholc }\end{array}$ & $\begin{array}{l}\text { Singh } \\
\text { and } \\
\text { Siddique } \\
(2014)\end{array}$ \\
\hline Specificgravity & 1.39 & 2.19 & 1.5 & 1.87 & 2.09 & 2.47 & 1.39 \\
\hline $\begin{array}{l}\text { Water } \\
\text { absorption (\%) }\end{array}$ & 6.10 & 28.9 & 30.4 & 5.45 & 13.6 & 7.0 & 31.58 \\
\hline $\begin{array}{l}\text { Fineness } \\
\text { Modulus }\end{array}$ & - & 1.83 & - & 2.36 & - & 2.8 & 1.37 \\
\hline
\end{tabular}

\section{Chemical Properties of Coal Bottom Ash}

Coal fiery remains created on consuming of lignite or sub bituminous coal contains high calcium oxide content. This sort of coal fiery remains has cementitious properties notwithstanding pozzolanic properties. Anthracite or bituminous coals on consuming outcome in low-calcium coal fiery debris which has pozzolanic properties and little part of calcium oxide (ASTM C 618-03). Coal base Ash is essentially made out of silica, alumina and iron with little measures of calcium, magnesium, sulfate and so on. Its substance organization is controlled by the wellspring of the coal. The information revealed in distributed writing demonstrates variety in synthetic sythesis of Coal Bottom Ash remains. Table-2 shows the chemical composition of coal bottom ash reported in published literature. 
Table 2. Chemical composition of coal bottom ash

\begin{tabular}{|c|c|c|c|c|c|c|c|}
\hline $\begin{array}{l}\text { Chemical } \\
\text { composition } \\
\text { (\%) }\end{array}$ & $\begin{array}{l}\text { Yuksel } \\
\& \text { Genc } \\
(2007)\end{array}$ & $\begin{array}{c}\text { Bai et al. } \\
(2005)\end{array}$ & $\begin{array}{c}\text { Aramraks } \\
(2006)\end{array}$ & $\begin{array}{l}\text { Kasemchaisiri } \\
\text { \&Tangtermsirikul } \\
(2007)\end{array}$ & $\begin{array}{c}\text { Muhardi } \\
\text { et al. }\end{array}$ & $\begin{array}{l}\text { Gafoori } \\
\text { \&Bucholc } \\
(1996)\end{array}$ & $\begin{array}{l}\text { Singh } \\
\text { and } \\
\text { Siddique }\end{array}$ \\
\hline $\mathrm{SiO}_{2}$ & 57.90 & 54.8 & 46.20 & 38.64 & 42.7 & 41.70 & 56.44 \\
\hline $\mathrm{Ai}_{2} \mathrm{O}_{2}$ & 22.60 & 28.5 & 23.11 & 21.15 & 23.00 & 17.10 & 29.24 \\
\hline $\mathrm{Fe} 2 \mathrm{O} 3$ & 6.50 & 8.49 & 8.62 & 11.96 & 17.00 & 6.63 & 8.44 \\
\hline $\mathrm{CaO}$ & 2.00 & 4.2 & 12.12 & 13.80 & 9.80 & 22.50 & 0.75 \\
\hline $\mathrm{MgO}$ & 3.20 & 0.35 & 2.90 & 2.75 & 1.54 & 4.91 & 0.40 \\
\hline $\mathrm{Na} 2 \mathrm{O}$ & 0.086 & 0.08 & 0,55 & 0.90 & 0.29 & 1.38 & 0.09 \\
\hline $\mathrm{K}_{2} \mathrm{O}$ & 0.604 & 0.45 & 2.13 & 2.06 & 0.96 & 0.40 & 1.29 \\
\hline TiO2 & - & 2.71 & - & - & 1.64 & \multirow{2}{*}{$\begin{array}{l}3.83 \\
\left(\mathrm{P}_{2} \mathrm{O} 5\right. \\
\mathrm{TiO}_{2}\end{array}$} & 3.36 \\
\hline $\mathrm{P}_{2} \mathrm{O}_{5}$ & - & 0.28 & - & - & 1.04 & & - \\
\hline $\mathrm{SO} 3$ & & - & 0.42 & 0.61 & 1.22 & 0.42 & 0.24 \\
\hline LOI & 2.40 & 2.46 & & 7.24 & - & 1.13 & 0.89 \\
\hline
\end{tabular}

\section{Mineralogy Characteristics of Coal Bottom Ash}

Results of X-ray diffraction (XRD) analysis of pure coal bottom ash carried out by Muhardi et al. (2010) show that mullite (A16Si2O13), silicon oxide (SiO2) and silicon phosphate are the predominant crystalline form substances. They observed that silica $(\mathrm{SiO} 2)$ is present partly in the crystalline forms of quartz (SiO2) and partly in combination with the alumina as mullite (Al6Si2O13). The iron appears partly as the oxide magnetite (Fe3O4) and hematite (Fe2O3). The composition of coal bottom ash depends on the composition of coal and furnace condition. Alumino silicates such as clays melt or decompose to form glass or mullite (Al6Si2O13). Carbonates including calcite (CaCO3), dolomite $[\mathrm{CaMg}(\mathrm{CO} 3) 2]$ ankerite [CaMgxFe(1-x)(CO3)2] and siderite (FeCO3) decompose, release $\mathrm{CO} 2$ and form lime $(\mathrm{CaO})$, calcium ferrite (CaFe2O4), hematite (Fe2O3), magnetite $(\mathrm{Fe} 3 \mathrm{O} 4)$ and periclase $(\mathrm{MgO})$. Sulphides such as pyrite (FeS2) oxidize, loose $\mathrm{SO} 2$ and form sulfates (SO3). Iron oxides such as hematite (Fe2O3) and magnetite (Fe3O4), chlorides volatilize as $\mathrm{NaCl}$ and $\mathrm{KCl}$. Quartz (SiO2) generally remains unaltered.

\section{Environmental Impact of Coal Bottom Ash}

The present strategy for transfer of Coal Bottom Ash in lakes postures hazard to human wellbeing and to the earth. The perilous constituents in Coal Bottom Ash debris relocate and can pollute ground water or surface water, and thus influence living life forms. What's more, there is peril of fiery remains dyke spills and filling the region encompassing to the slag lake with coal powder. In year 2008, fiery debris dyke at Kingston plant, USA, fizzled and coal Ash overflowed 12 homes, spilled into close-by Watts Bar 
Lake, and debased the Emory River. Almost 5.4 million cubic yard of fiery remains spilled which secured around 400 sections of land of adjoining area.

Fig. 1.2 demonstrates the site of slag dyke disappointment at Kingston plant (USA). The tidy up operation cost was about $\$ 200$ million. It took around 6 years to tidy up the range from the fiery debris slurry. This spill is named as one of the most exceedingly bad ecological calamities in the historical backdrop of the United States.

Ash dyke disappointments at NTPC's Simhadri plant in Vishakhapatnam (India) in 2010 and Rajiv Gandhi warm power plant, Hissar, Haryana (India) in 2012 have likewise been accounted for. Fiery remains dykes of Hindalco hostage control plant ruptured in 2012 and harmed crops at Hirakud, (India). A huge number of huge amounts of coal fiery debris streamed into the Satluj River because of a rupture in the southern Ash dyke of the Guru Gobind Singh Super Thermal Plant (GGSSTP), Ropar, Punjab (India) in 2002. Fiery debris dykes at GGSSTP,Ropar had broken number of time. The general population living in the close-by range are under steady danger of fiery remains dyke ruptures. Because of persistent leakage of water from fiery debris lakes, arrive abutting to lake site has changed over into water logged arrive.

The rises made by dumping of coal Ash are getting to be noticeably ecological dangers to the encompassing groups. In perspective of natural issues postured by dumping of coal fiery remains, it is basic to use coal slag and devise ways and intends to chop down the development of coal Ash amassing. The gainful use of the coal slag is the main condition amicable answer for the issues related with its transfer.

\section{Uses of Coal Bottom Ash}

Coal bottom ash can be beneficially utilized in a variety of manufacturing and construction applications. Fig.1.3 illustrates the common uses of bottom ash. At present in USA, coal bottom ash is predominantly being used for the following applications: -

- Road base and sub-base

- Structural fill

- Backfill

- Drainage media

- Aggregate for concrete, asphalt and masonry

- Abrasives/traction

- Manufactured soil products

- Snow and ice control

\section{SIGNIFICANCE OF RESEARCH}

Degradation of environment takes place mainly due to: i) accumulation of industrial waste products; ii) excessive extraction of the natural resources, which are depleting gradually. In the developing countries like India, large volumes of coal ash are getting accumulated near the coal fired power plant sites and are becoming environmental nuisance for the surrounding community.

There has been developing pattern of use of the waste materials around the world. Fly fiery remains has been being used in assembling of bond and cement since long. Be that as it may, utilization of coal base Ash as an admixture or fine Aggregate underway of cement is not basic all through the world. It is in this manner required to analyze the Coal Bottom Ash for its conceivable uses in cement. Endeavors have been made in the created nations like USA to locate the productive employments of high-calcium coal base Ash. In a couple look into works high-calcium coal base Ash has been focused as fine Aggregate in cement. Nonetheless, in India, no noteworthy exertion has been made in this regard. The distributed writing is lacking to get Coal Bottom Ash debris functional utilize. In that capacity, Coal Bottom Ash remains is not utilized as a part of any frame. The utilization of Coal Bottom Ashwill fill two needs, right off the bat the transfer of this waste material, also, use as development material, and 
aiding in protecting the characteristic assets. The usage of a mechanical by item has an imperative bearing on keeping up the biological adjust and economy of a nation when all is said in done and development industry specifically

\section{POLYPROPYLENE FIBRE}

For quite a while, the polymers of propylene, a modest oil subordinate, were referred to just as gooey oils of minimal business value. These oils, with a thickness extend subordinate upon the atomic weight of the polymer, were not solidified by the strategies for polymerization known to deliver a crystalline structure in such materials as ethylene, vinylidenechloride, and perfluoroethylene. Nonetheless, in 1954, Professor G. Natta found another polymerization component which could change the arbitrary auxiliary course of action of these "non-crystallizable" polymers into structures of high synthetic and geometrical consistency. These polymers, comprising of straight particles in which the concoction gatherings are routinely orchestrated along the macromolecule, are exceedingly crystalline and thus show exceptional physical properties contrasted with their nebulous partners.

\section{FIBRE REINFORCED CONCRETE (FRP)}

Customary fiber fortified cement, here and there called FRC, is solid that has been reinforced by adding shreds of different materials to the wet solid blend. Cement is very weak; it has great compressive quality however nearly minimal rigidity, which makes it liable to break under many conditions. Breaking prompts additionally harm. Fiber fortified cement is less inclined to break than standard cement. Utilizing filaments to strengthen is not another thought. Actually, it has been polished for a great many years, with straw blended into mud blocks and horsehair incorporated into motar. In the early years of the twentieth century, asbestos strands were added to concret. By the 1960s an assortment of materials, for example, polypropylene, glass, and steel strands, were utilized as a part of fiber fortified cement. Ebb and flow inquire about recommends that microfibers, as opposed to long strands, best increment elasticity. In any case, including strands causes generally little change in effect resistance. Polypropylene SYNTHETIC filaments lessen harm from stop -thaw cycles and decrease the odds of spalling or blast if there is a fire. Cellulose filaments from hereditarily altered pine trees have likewise demonstrated guarantee in testing.

\section{ADVANTAGES OF POLYPROPYLENE FIBRE}

- They distribute localized stresses, thereby reducing damage from impact, flexural fatigue, and shatter, spalling and cracking in hardened concrete.

- $\quad$ They help in reducing maintenance and repair cost. They provide a tough and durable surface.

- The help in saving time due to speed and convenience of concrete placing and flexibility.

- Improve mix cohesion, improving Pumpability over long distance

- Improve freeze-thaw resistance

- Improve resistance to explosive spalling in case of a severe fire

- Improve impact resistance

- Increase resistance to plastic shrinkage during curing

\section{ALTERNATIVE MATERIALS TO SAND}

Some of the alternative materials like crushed rock material; M-sand, fly ash and sea sand are found out in order to replace the natural sand. Boulders of rock are crushed to small pieces in crushers to obtain different sizes of metal like $40 \mathrm{~mm}, 20 \mathrm{~mm}, 10 \mathrm{~mm}$, $4.75 \mathrm{~mm}$ and the powder residue of size less than 4.75 $\mathrm{mm}$. The powder is the unwanted material called as quarry dust and this is dumped like heap of mountain near crusher units which creates environmental 
pollution. It is used as filler to spread over newly laid bituminous road surface. If it is effectively used in concrete as an alternate material to sand, it helps to reduce environmental pollution. Its cost is less when compared to river sand.

The M-sand, the manufactured sand is prepared by washing quarry dust, dried and then sieved through $4.75 \mathrm{~mm}$ sieve. The particles having size in between $4.75 \mathrm{~mm}$ to 150 microns is called as M-sand. It is costlier than quarry dust but cheaper than river sand. Fly ash generated and sintered ash from pulverized coal burner is an important aggregate. Large quantities of this industrial by-product are derived from pulverized coal operated boilers of thermal stations. These ashes are extensively used by the building industry. Ash as pozzolana is used for cellular and other types of concrete as mineral admixtures. Fly ash also used as fine aggregate as a partly replacement material.

Among the above alternative materials to sand, quarry dust is preferred and Fly ash for cement for this study.

\section{QUARRY DUST}

Quarry dust, a by-product from the crushing process of stones (Blue metal) which is available abundantly from rock quarries at low cost in many areas can be an economical alternative to the river sand. Quarry dust can be defined as residue, tailing material after the extraction and processing of rocks to form fine particles less than $4.75 \mathrm{~mm}$ (Ilangovan et al 2008). Quarry dust, which is generally considered as a waste material, causes an environmental load due to disposal problem. Quarry dust being by and large, a waste product, will also reduce environmental impact, if consumed by construction industry in large quantities (Raman et al 2007). Hence, the use of quarry dust as fine aggregate in concrete will reduce not only the demand for natural sand but also reduces the environmental problems ((Illangovan and Nagamani et al 2006). Moreover, the incorporation of quarry dust will offset the production cost of concrete and hence, the successful utilization of quarry dust as fine aggregate will turn this waste material into valuable resource (Illangovan et al 2008 and Nataraja et al 2001).

Quarry dust has been used for different activities in the construction industry such as for road construction and manufacture of building materials such as lightweight aggregates, bricks, tiles and autoclave blocks (Radhikesh et al 2010).Usually, quarry dust is used in large scale in the highways as a surface finishing material. Use of quarry dust as fine aggregate in concrete draws serious attention of researchers and investigators (Hameed and Sekar 2009, Ahmed 1989). The utilization of well graded, fines free quarry dust has been accepted as building material in the industrially advanced countries (Manasseh Joel 2010, Hudson 1997) of the west for the past three decades. As a result of sustained research and development works under taken, with respect to increasing application of this industrial waste (Nagaraj 2000). The level of utilization of quarry dust in the countries like Australia, France, Germany and UK has been reached more than $60 \%$ of its production. The use of quarry dust in India has not been much, when compared with other advanced countries (Narasimhan et al 1999).

Complete replacement of quarry dust in concrete is possible with proper treatment of quarry dust before utilization (Illangovan et al 2008). Concrete containing quarry dust as fine aggregate is promising greater strength, lower permeability and greater density which enable it to provide better resistance to freeze/thaw cycles and durability in adverse environment (Sahu et al 2003). It is found that the strength and durability properties of concrete made of quarry dust are nearly $10 \%$ more than that of the conventional concrete (Nagamani et al 2006). Thus 
the quarry dust can be used for all types of concrete including self compacting concrete, high performance concrete, pumpable concrete, roller compacted concrete, precast concrete products, brick work and plaster mortars, flooring and water proofing (PrakashRao and Gridhar 2004).

The addition of quarry dust directly affects the workability, because the quarry dust has least permeability, more surface area and requires more water (Reddy et al 2002). Hence, in order to attain the desired workability at constant water cement ratio, super plasticizers can be used in quarry dust replaced concrete (Murugesan et al 2006). The use of super plasticizer has driven major advancements in the area of concrete technology for the past few decades. Addition of super plasticizer increases the workability as well as contributes to improve the compressive strength of concrete. Concrete produced using quarry dust along with plasticizer shows improvement in compressive strength, higher flexural strength, abrasion resistance, and unit weight which are very important for reducing corrosion or leaching (Murugesan et al 2006).

\section{SCOPE}

- Characterization of material

- Design of conventional concrete mix

- Preparation of concrete mixtures with varying sand replacement levels

- $\quad$ Studyingthepropertiesoffreshcontrolconcreteas wellasbottomashconcrete and Quarry Dust mixture

- $\quad$ Casting of specimens of control concrete as well as bottom ash concrete mixtures

- Dosage of the Bottom Ash used are 10\%, 20\% \& $30 \%$ of the Aggregate Fine Aggregate.

- Dosage of the Quarry Dust used are 10\%, 20\% \& 30\% of the Aggregate Fine Aggregate.
- Dosage of the Polypropylene Fibre used are $0.5 \%, 1 \%$ and $1.5 \%$ of the Aggregate weight of the Cube.

- $\quad$ Proportions are

- BA $10 \%$

- BA $20 \%$

- BA $30 \%$

- QD $10 \%$

- QD 20\%

- QD 30\%

- $0.5 \% \mathrm{PF}$

- $1.0 \% \mathrm{PF}$

- $1.5 \% \mathrm{PF}$

- Combined applications

- BA $20 \%+$ QD 30\% + 0.5\% PF

- BA 20\% + QD 30\%+1.0\% PF

- $\mathrm{BA} 20 \%+\mathrm{QD} 30 \%+1.5 \% \mathrm{PF}$

\section{Properties of M30 Grades of concrete:}

$>$ Compressive Strengths of concrete at 3, 7, 28, $56 \& 90$ days

$>$ Tensile Strength of concrete at 28 days

$>$ Flexural Strength of concrete at 28 days

$>$ Modulus of Elasticity of concrete for 28 days

$>$ Sulphate attack is performed for 28 days

\section{Applications of High-Performance Fibre-Reinforced Cement-Based Composite}

Propelled composites and the major comprehension of their conduct is a quickly extending branch inside the field of structural designing materials. Specifically, fiber-fortified concrete based materials have had an extraordinary development in these years, with the goal that they are increasingly used in the building part. Furthermore, substantial endeavors have been made to grow elite bonds and cements indicating further execution changes. Elite fiber-fortified bond composites incorporate, for instance, materials, for example, SIFCON (Slurry Infiltrated Fiber Concrete), Fiber-strengthened DSP (Densified with Small Particles), and fiber-strengthened MDF (Macro- 
Defect-Free) concretes. Advancements of these materials were conceivable due to: (a) the presentation of new fortification frameworks; (b) the improvement of elite bond based grids, which display enormously enhanced miniaturized scale auxiliary properties as far as quality and strength; (c) the improvement of sufficient handling systems (counting controlling compound responses) which enable us to get composite materials with shocking sturdiness properties. After a short depiction of elite concrete based networks and relative composites, two unique cases among the above-refered to items will be profoundly displayed. From the above depiction it can be seen that fiber-strengthened DSP and MDF items are ease back to discover beneficial outlets.

In the primary case (DSP and relative items), there are confinements for basic applications, most importantly, because of the high material cost and to the absence of configuration principles and measures including high quality cements: current applications are just in extraordinary market specialties. MDF composites are exceptionally encouraging materials which offer surprising properties regarding processability and durability properties, in any case, right now, their commercialisation is by all accounts constrained by the water affectability.

\section{PROPERTIES OF MATERIALS}

The main constituents of the concrete Cement, fine aggregate, Coarse aggregate, Water, Ash are procured from various places. Fine aggregate is procured from local Quadramangalam near Tiruchanoor. Coarse aggregate is procured from Chandragiri quarry (machine crushed). Local drinking water is used for mixing and curing.The Bottom Ash is procured from the Astra chemicals, Mumbai. Quarry dust is procured from quarry at Chandragiri.

\section{Materials}

The materials used in the experimental investigation include:

1. 53 grade Ordinary Portland Cement (OPC)

2. Fine Aggregates(Sand)

3. Coarse Aggregate

4. Water

5. Coal Bottom Ash (CBA)

6. Quarry Dust (QD)

7. Polypropylene Fibre (PF)

\section{Cement}

Ultratech Ordinary Portland Cement (OPC) of 53 grade of Cement conforming to IS: 12269 standards has been procured and various tests have been carried out according IS: 8112-1989 from them it is found that.

1. Specific Gravity of Cement is 3.15

2. Initial and Final setting times of Cement are $50 \mathrm{~min}$ and $480 \mathrm{~min}$ respectively

3. Fineness of cement is $6.0 \%$

\section{Fine Aggregate}

The locally available natural river sand is procured and is found to be confirmed to grading zone-I of Table 4 of IS 383-1970. Various tests have been carried out as per the procedure given in IS 383(1970) from them it is found that,

a) Specific Gravity of fine aggregate is 2.52

b) Fineness Modulus of Fine Aggregate is 3.19

The particle size distribution of sand was determined and the results are tabulated in below Table and below Figure shows the grading curve for upper and lower limit of zone-I sand and the fine aggregate used for Concrete preparation. 
Table 3. Sieve Analysis of Fine Aggregate

\begin{tabular}{|c|c|c|c|c|c|c|c|}
\hline \multirow{2}{*}{ Sieve Size } & $\begin{array}{c}\text { Weight } \\
\text { Retained } \\
(\mathrm{gm})\end{array}$ & $\begin{array}{c}\text { Cumulative } \\
\text { \% Retained }\end{array}$ & \multirow{2}{*}{$\begin{array}{c}\text { Cumulative } \\
\% \text { Passing }\end{array}$} & \multicolumn{5}{|c|}{ Zone - Specifications as perIS:383-1970 for } \\
\% Passing \\
\cline { 5 - 8 } & & & I & II & III & IV \\
\hline $10 \mathrm{~mm}$ & 0 & 0 & 100 & & & & \\
\hline $4.75 \mathrm{~mm}$ & 22 & 2.2 & 97.8 & $90-100$ & $90-100$ & $90-100$ & $95-100$ \\
\hline $2.36 \mathrm{~mm}$ & 46 & 6.8 & 93.2 & $60-95$ & $75-100$ & $85-100$ & $95-100$ \\
\hline $1.18 \mathrm{~mm}$ & 215 & 28.3 & 71.7 & $30-70$ & $55-90$ & $75-100$ & $90-100$ \\
\hline $600 \mu$ & 419 & 70.2 & 29.8 & $15-34$ & $35-59$ & $60-79$ & $80-100$ \\
\hline $300 \mu$ & 282 & 98.4 & 1.6 & $5-20$ & $8-30$ & $12-40$ & $15-50$ \\
\hline $150 \mu$ & 14 & 99.8 & 0.2 & $0-10$ & $0-10$ & $0-10$ & $0-10$ \\
\hline Pan & 2 & 100 & 0 & --- & --- & --- & -- \\
\hline
\end{tabular}

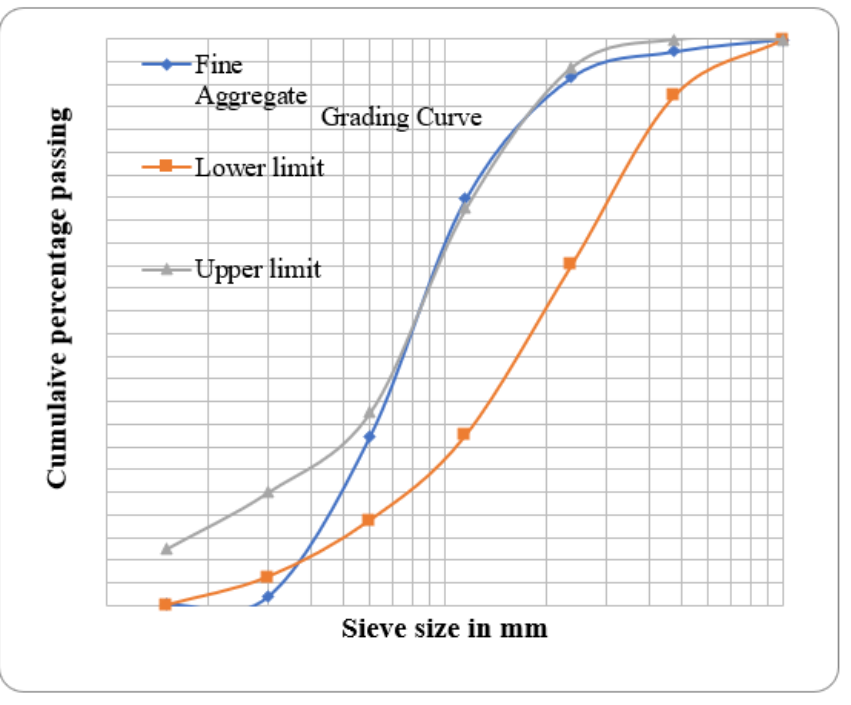

Figure 1. Particle Size Distribution of Fine Aggregate

\section{Coarse Aggregate}

Machine Crushed granite aggregate confirming to IS 383-1970 consisting $20 \mathrm{~mm}$ maximum size of aggregates has been obtained from the local quarry. It has been tested for Physical and Mechanical Properties such as Specific Gravity, Sieve Analysis, and the results are as follows.
1. Specific Gravity coarse aggregate is 2.7

2. Fineness Modulus of Coarse Aggregate 3.36

The particle size distributions of coarse aggregate were determined and the results are tabulated in below Table and below Figure shows the grading curve for coarse aggregate used for Concrete preparation.

Table 4. Sieve Analysis of Coarse Aggregate

\begin{tabular}{|c|c|c|c|}
\hline $\begin{array}{c}\text { Sieve } \\
\text { Size }\end{array}$ & $\begin{array}{c}\text { Weight } \\
\text { Retained(kg) }\end{array}$ & $\begin{array}{c}\text { Cumulative } \\
\% \text { Retained }\end{array}$ & $\begin{array}{c}\text { Cumulative } \\
\% \text { Passing }\end{array}$ \\
\hline $80 \mathrm{~mm}$ & 0 & 0 & 100 \\
\hline $40 \mathrm{~mm}$ & 0 & 0 & 100 \\
\hline $20 \mathrm{~mm}$ & 5.2 & 52 & 48 \\
\hline $10 \mathrm{~mm}$ & 4.8 & 100 & 0 \\
\hline 4.75 & 0 & 100 & 0 \\
$\mathrm{~mm}$ & & 100 & 0 \\
\hline $\begin{array}{c}2.36 \\
\mathrm{~mm}\end{array}$ & 0 & 100 & 0 \\
\hline 1.18 & 0 & & \\
$\mathrm{~mm}$ & & 100 & 0 \\
\hline $600 \mu$ & 0 & 100 & 0 \\
\hline $300 \mu$ & 0 & 100 & 0 \\
\hline $150 \mu$ & 0 & & \\
\hline
\end{tabular}




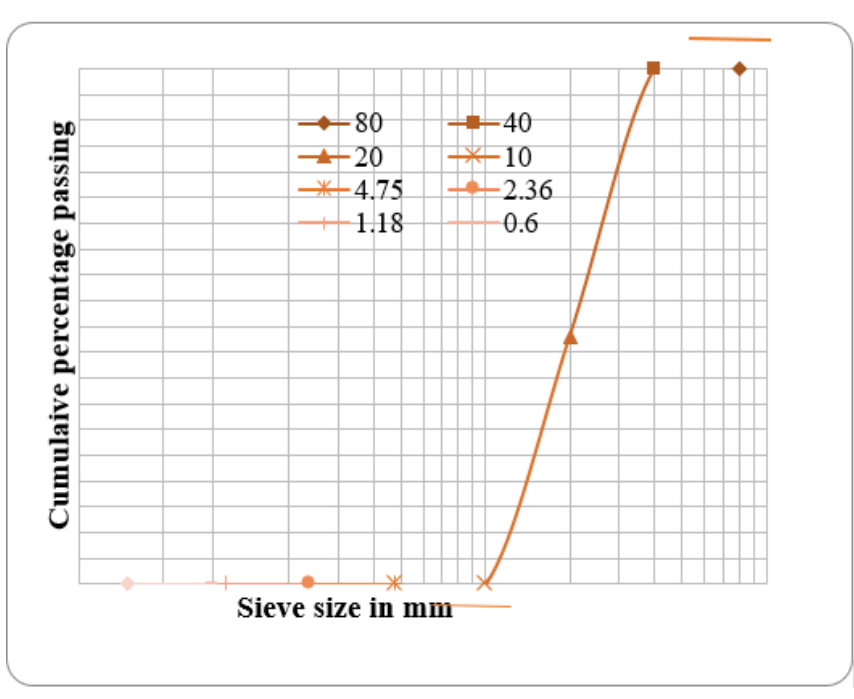

Figure 1. Particle Size Distribution of Coarse Aggregate

\section{Water}

Local Drinking water free flow impurities has been used in this experimental program for mixing and curing.

\section{Coal Bottom Ash}

Bottom ash is part of the non-combustible residue of combustion in a furnace or incinerator. In an industrial context, it usually refers to coal combustion and comprises traces of combustibles embedded in forming clinkers and sticking to hot side walls of a coal-burning furnace during its operation. The portion of the ash that escapes up the chimney or stack is, however, referred to as fly ash. The clinkers fall by themselves into the bottom hopper of a coalburning furnace and are cooled. The above portion of the ash is referred to as bottom ash. Coal Bottom Ash was procured from Astrra Chemicals, Mumbai. Coal Bottom Ash is as shown in below Figure.

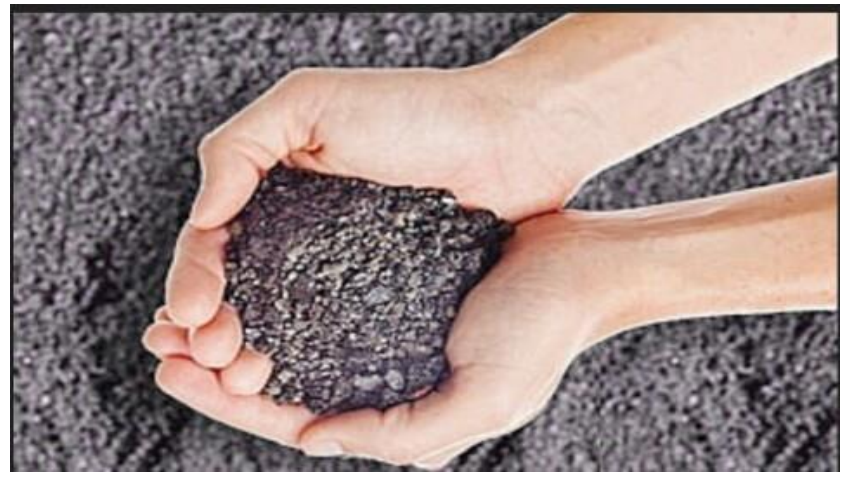

Figure 2. Figure showing the Coal Bottom Ash (CBA)

\section{Polypropylene Fibre (PF):}

Polypropylene (PP), also known as polypropene, is a thermoplastic polymer used in a wide variety of applications including packaging and labeling, textiles, stationery, plastic parts and reusable containers of various types, laboratory equipment, loudspeakers, automotive components, and polymer banknotes. An addition polymer made from the monomer propylene, it is rugged and unusually resistant to many chemical solvents, bases and acids.

Polypropylene has a relatively slippery "low energy surface" that means that many common glues will not form adequate joints. Joining of polypropylene is often done using welding processes. Polypropylene Fibre properties are explained in below Table and Molecular Structure is shown in below Figure.

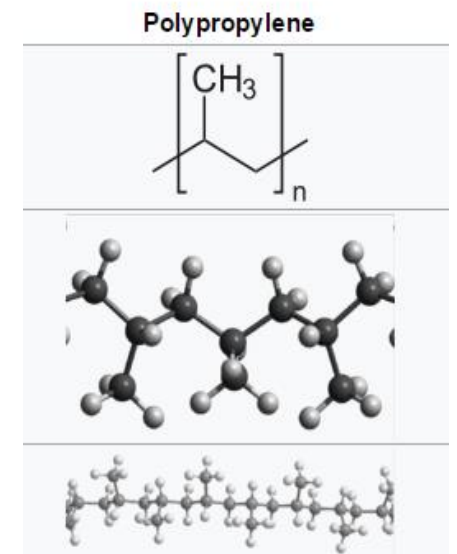

Figure 3. Molecular Structure of Polypropylene 
Table 5. Properties of Polypropylene Fibre

\begin{tabular}{|c|c|c|}
\hline S No & Properties & Value ( As per MTC) \\
\hline 1 & $\begin{array}{c}\text { Specific gravity } \\
\text { of fibre }\end{array}$ & $0.9-0.91$ \\
\hline 2 & Length & $6 \mathrm{~mm}$ to $12 \mathrm{~mm}$ \\
\hline 3 & $\begin{array}{c}\text { Water } \\
\text { absorption } \\
\text { (The water absorption } \\
\text { of polypropylene fibre } \\
\text { is about } 0.3 \% \text { after } 24 \\
\text { hours immersion in } \\
\text { water, and thus its } \\
\text { regain - the amount } \\
\text { of water absorbed in a } \\
\text { humid atmosphere - } \\
\text { is virtually nil) }\end{array}$ \\
\hline
\end{tabular}

\section{Quarry Dust (QD):}

The crushed rock particles having size below 4.75 $\mathrm{mm}$ is defined as fine aggregate. It is further classified into coarse, medium and fine. The sizeof grains from $4.75 \mathrm{~mm}$ to $2 \mathrm{~mm}$ is known as coarse, $2 \mathrm{~mm}$ to $0.425 \mathrm{~mm}$ as medium and $0.425 \mathrm{~mm}$ to $0.075 \mathrm{~mm}$ defined as fine. Tests were conducted to determine specific gravity, density and void ratio and are shown in below Table and the Sample is as shown in below Figure.

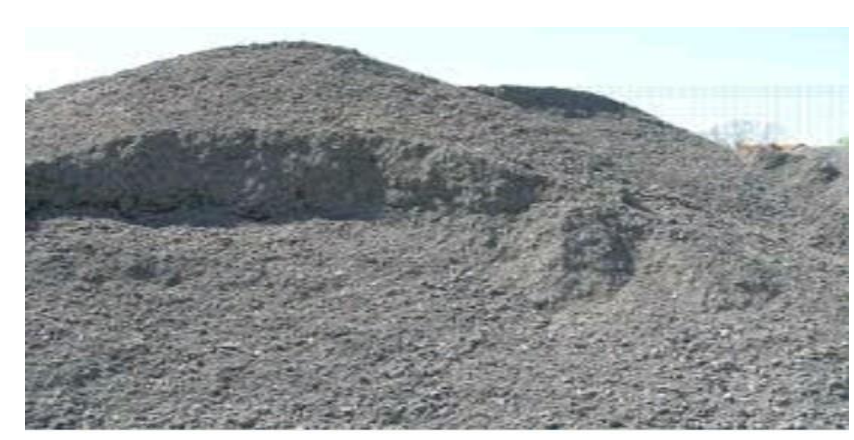

Figure 4. Quarry Dust Sample
Table 6. Properties of Quarry Dust

\begin{tabular}{|c|c|c|}
\hline S.No. & Property & Value \\
\hline 1 & Specific Gravity & 2.57 \\
\hline 2 & Fineness Modulus & 2.41 \\
\hline 3 & Density & $1.85 \mathrm{gm} / \mathrm{cc}$ \\
\hline 4 & Void Ratio & 0.42 \\
\hline
\end{tabular}

\section{CONCRETE MIX DESIGN}

Cement is a composite material with heterogeneous properties that are imperatively reliant on the sum and properties of the constituents. The Concrete blend configuration is a fundamental instrument in all parts of solid innovation and its prime target is to accomplish the required compressive quality and workability. Very much created blend outline strategies are in this way prime apparatuses in securing manageable mechanical solid development methods. In this proposition, use of powerful molecule pressing idea for blend outline of typical quality cement is embraced. The solid blend is planned according to The Indian Standard (IS: 102621982) technique.

\section{IS METHOD}

The IS technique prescribed the amendment variables for various w/c proportions, workability and for shape coarse Aggregate. The amounts of fine and coarse Aggregate are computed with help of conditions, which depend on particular gravities of the fixings. In this way plastic thickness of cement ascertained from yield condition is by and large anticipated that would be nearer to real plastic thickness gotten in research facility. In this way real bond utilization will be near that focused in the main trial blend itself. The water bond proportion is figured from concrete bends in light of 28 days quality of bond. The IS has suggested rules for solid blend configuration in light of bond and different 
materials locally accessible. The plan ventures for blend proportioning as suggested in IS : 10262-1982, are examined beneath:

\section{Mix Design for M30 Grade of Concrete}

Table 7. Mix Design of M25 Grade

\begin{tabular}{|c|c|}
\hline Grade Designation & M30 \\
\hline $\begin{array}{c}\text { Type of Cement } \\
\text { Maximum Nominal size of } \\
\text { Aggregate }\end{array}$ & OPC $53 \mathrm{Grade}$ \\
\hline $\begin{array}{c}\text { Minimum content of } \\
\text { Cement }\end{array}$ & $320 \mathrm{Kg} / \mathrm{m}^{3}$ \\
\hline $\begin{array}{c}\text { Maximum Water Cement } \\
\text { ratio }\end{array}$ & 0.45 \\
\hline $\begin{array}{c}\text { Workability } \\
\text { Maximum cement } \\
\text { content }\end{array}$ & $450 \mathrm{Kg} / \mathrm{m}^{3}$ \\
\hline $\begin{array}{c}\text { Specific Gravity of } \\
\text { Cement }\end{array}$ & 3.15 \\
\hline $\begin{array}{c}\text { Specific Gravity of Coarse } \\
\text { Aggregate }\end{array}$ & 2.7 \\
\hline $\begin{array}{c}\text { Specific Gravity of Fine } \\
\text { Aggregate }\end{array}$ & 2.52 \\
\hline
\end{tabular}

Target Mean Strength

$$
\begin{array}{ll}
F_{c k}{ }^{1}= & F_{c k}+1.65 \mathrm{~s} \\
= & 30+1.65 \times 5.0 \\
= & 38.25 \mathrm{~N} / \mathrm{mm}^{2}
\end{array}
$$

\section{Selection of Water Cement ratio:}

From table 5 (IS 456) maximum water cement ratio = 0.50

Minimum cement content $=320 \mathrm{Kg} / \mathrm{m}^{3}$

Minimum water content $=320 \times 0.45=144 \mathrm{Litres}$

\section{Selection of water content:}

Estimated water content for $100 \mathrm{~mm}$ slump $=$ $144+((6 / 100) \times 144)=153.0$ Litres
$=340 \mathrm{Kg} / \mathrm{m}^{3}\left(>300 \mathrm{Kg} / \mathrm{m}^{3}\right)$

Estimated water content $=340 \times 0.45=153$ Litres

\section{Proportion of volume of Coarse Aggregate and Fine} Aggregate content

From Table 3 (IS 10262: 2009) Volume of Coarse Aggregate corresponding to $20 \mathrm{~mm}$ size aggregate and Fine Aggregate (Zone - I) for Water Cement ratio of 0.45

Volume of Coarse Aggregate $=0.61$ (for ZoneI Table No.3 IS 10262 -2009)

Volume of Fine Aggregate $=1-0.61=0.39$

\section{Mix Calculations:}

Volume of Concrete $=1 \mathrm{~m}^{3}$

$$
\text { Volume of Cement }=\frac{\text { Mass of Cement } \times \quad 1}{\text { Specific Gravity of Cement } \times 1000}
$$$$
=(340 / 3.15) \times(1 / 1000)=0.1079 \mathrm{~kg} / \mathrm{m}^{3}
$$$$
\text { Volume of Water }=
$$

$\begin{array}{cl}\text { Mass of Water } \times 1 \\ \text { Specific Gravity of Water } \times & 1000\end{array}$

$$
=(153 / 1.0) \times(1 / 1000)=0.153 \mathrm{~kg} / \mathrm{m}^{3}
$$

Volume of All in Aggregate. $=1-\{$ Volume of cement + Volume of water 3

$$
=1-[0.1079+0.153]=\quad 0.739 \mathrm{~kg} / \mathrm{m}^{3}
$$

Mass of Coarse Aggregate $=$ Volume of all in aggregate $\times$ Volume of C.A $\times$ specific gravity of C.A $\times$ $1000=0.739 \times 0.61 \times 2.7 \times 1000=1217 \mathrm{~kg} / \mathrm{m}^{3}$ Mass of Fine Aggregate $=$ Volume of all in aggregate $\times$ Volume of F.A $\times$ specific gravity of F.A $\times 1000=$ $0.739 \times 0.39 \times 2.52 \times 1000=\quad 726 \mathrm{~kg} / \mathrm{m}^{3}$
1: 2.13: $3.57: 0.45$

\section{Calculations of cement content}

Estimated cement content $=153 / 0.45$ 
Table 8. Quantities of Ingredients per cum of M30 Grade Concrete

\begin{tabular}{|c|c|c|c|c|c|c|c|}
\hline Concrete & $\begin{array}{c}\text { Cemen } \\
\mathrm{t}(\mathrm{Kg})\end{array}$ & $\begin{array}{c}\text { Bottom } \\
\text { Ash } \\
(\mathrm{Kg})\end{array}$ & $\begin{array}{c}\text { Quarry } \\
\text { Dust (Kg) }\end{array}$ & $\begin{array}{c}\text { Polypropylene } \\
\text { Fibre } \\
(\mathrm{Kg})\end{array}$ & $\begin{array}{c}\text { Water } \\
(\mathrm{Lit})\end{array}$ & $\begin{array}{c}\text { Fine } \\
\text { Aggregate } \\
(\mathrm{kg})\end{array}$ & $\begin{array}{c}\text { Coarse } \\
\text { Aggregate } \\
(\mathrm{kg})\end{array}$ \\
\hline Control & 340 & 0 & 0 & 0 & 159 & 726 & 1217 \\
\hline BA 10\% & 340 & 72.6 & 0 & 0 & 159 & 653.4 & 1217 \\
\hline BA 20\% & 340 & 145.2 & 0 & 0 & 159 & 580.8 & 1217 \\
\hline BA 30\% & 340 & 217.8 & 0 & 0 & 159 & 508.2 & 1217 \\
\hline QD 10\% & 340 & 0 & 72.6 & 0 & 159 & 653.4 & 1217 \\
\hline QD 20\% & 340 & 0 & 145.2 & 0 & 159 & 580.8 & 1217 \\
\hline QD 30\% & 340 & 0 & 217.8 & 0 & 159 & 508.2 & 1217 \\
\hline PF 0.5\% & 340 & 0 & 0 & 12.21 & 159 & 726 & 1217 \\
\hline PF 1.0\% & 340 & 0 & 0 & 24.42 & 159 & 726 & 1217 \\
\hline PF 1.5\% & 340 & 0 & 0 & 36.63 & 159 & 726 & 1217 \\
\hline $\begin{array}{c}\text { BA 20\%+QD } \\
30 \%+\text { PF 0.5\% }\end{array}$ & 340 & 145.2 & 217.8 & 12.21 & 159 & 363.6 & 1217 \\
\hline $\begin{array}{c}\text { BA 20\% + QD } \\
30 \%+\text { PF 1.0\% }\end{array}$ & 340 & 145.2 & 217.8 & 24.42 & 159 & 363.6 & 1217 \\
\hline $\begin{array}{c}\text { BA 20\%+QD 30\% } \\
+ \text { PF 1.5\% }\end{array}$ & 340 & 145.2 & 217.8 & 36.63 & 159 & 363.6 & 1217 \\
\hline
\end{tabular}

\section{EXPERIMENTAL INVESTIGATION}

The experimental investigation is carried out to obtain the Compressive Strength, Split Tensile Strength and Flexural Strength of M30 grade of concrete by partial replacement of cement with Coal Bottom Ash,Quarry Dust \& Polypropylene Fibre. In the present investigation, Concrete specimens were prepared with various combinations of Coal Bottom Ash (10\%, 20\% \& 30\%), Quarry Dust (10\%, 20\% \& $30 \%)$ \& Polypropylene Fibre $(0.5 \%, 1 \%, 1.5 \%)$ cement replacement by weight.

\section{Concrete Mix Preparation}

It can be defined as the process of selecting suitable ingredients of concrete and determining their relative proportions with the objective of producing concrete of required strength and durability as economically as possible. The design of concrete mix is not a simple task on account of widely varying properties of the constituent materials.

Design of concrete mix requires complete knowledge of various properties of the constituent materials, the complications, in case of changes on these conditions at the site. Initially the ingredients such as cement, Coal Bottom Ash (BA),Quarry Dust (QD)\& Polypropylene Fibre (PF) are mixed, to which the fine aggregate and coarse aggregate are added and thoroughly mixed and Water is measured exactly. Then it is added to the dry mix and it is thoroughly mixed until a mixture of uniform color and consistency is achieved which is then ready for casting. Prior to casting of specimens, workability is measured in accordance with the code IS 1199-1959 and determined by slump and compaction factor tests.

\section{Casting of Test Specimens}

After the completion of workability tests, the concrete has been placed in the standard metallic moulds in three layers and compacted each time by tamping rod. Before placing the concrete inner faces of the mould are coated with the machines oil for easy removal of test specimens and the surface of the specimens have been finished smoothly.

\section{Curing Procedure}

After the casting of Cubes, The specimens are kept at room temperature for one day and the specimens are removed from the moulds after 24 hours of casting of concrete specimens. Marking has been done on the specimens to identify the casting items. To maintain the constant moisture on the surface of the specimens, they are placed in water tank for curing. All the specimens have been cured for the desired age. Concrete specimens are cured for 3, 7, 28,56\& 90days.

Similarly ordinary M30 concrete Cubes, Cylinders \& Standard Beams (size $100 \mathrm{~mm} \times 100 \mathrm{~mm} \times 500 \mathrm{~mm}$ ) were casted as per the design mix proportion and cured under the above mentioned standard conditions for 28 days for testing. 


\section{Compressive Strength Test:}

Compression test is the most common test conducted on hardened concrete, because it is an easy test to perform, and most of the desirable characteristic properties of concrete are qualitatively related to its compressive strength. Compression test is carried out on specimen of cubical or cylindrical in shape. Compression test is done confirming to IS: $516-1959$. All the concrete specimens that are tested in a 200 tones capacity of the compression-testing machine. Concrete cubes of size $150 \mathrm{~mm} \times 150 \mathrm{~mm} \times 150 \mathrm{~mm}$ and Standard Cylinders of sizes $150 \mathrm{~mm}$ (dia) and 300 $\mathrm{mm}$ (height) were tested for compressive strength. Compressive strength of concrete is determined by applying load at the rate of $140 \mathrm{~kg} / \mathrm{sq} . \mathrm{cm} /$ minute till the specimens failed.

After 3, 7, 28,56\& 90 days.of curing, cube specimens were removed from the curing tank and cleaned to wipe off the surface water. Cubes were tested at the age of $3,7,28,56 \& 90$ days.using compression testing machine as shown in Fig 5.1. The maximum load to failure at which the specimen breaks and the pointer starts moving back was noted. The test was repeated for the three specimens and the average value was taken as the mean strength.

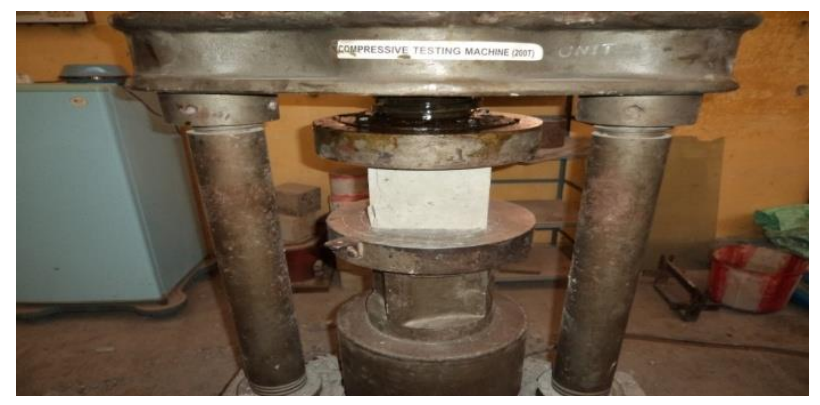

Figure 5. Cube Compression Test Apparatus

\section{Split Tensile Strength:}

This test is conducted in a 200 tones capacity of the compression-testing machine by placing the cylindrical specimen of the concrete, so that its axis is horizontal between the plates of the testing machine. Experimental setup for Split tension test is shown in
Fig.5.2 .The load was applied uniformly at a constant rate until failure by splitting along the vertical diameter takes place. Load at which the specimen failed is recorded and the splitting tensile stress is obtained using the formula based on IS: 5816-1970. The following relation is used to find out the split tensile strength of the concrete

$\mathrm{Ft}=2 \mathrm{P} / \pi \mathrm{DL}$

Where $\mathrm{P}=$ Compressive load on the cylinder

$\mathrm{L}=$ Length of the cylinder

$\mathrm{D}=$ Diameter of the cylinder

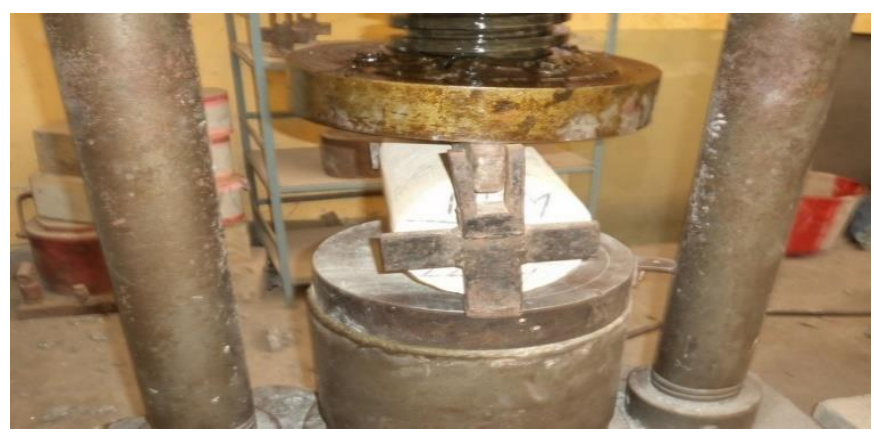

Figure 6. Split Tensile Test Apparatus

\section{Flexural Strength}

Flexural strength is one measure of the tensile strength of concrete. It is a measure of an unreinforced concrete beam to resist failure in bending. The flexural strength can be determined by Standard test method. In this study, three beams of size $100 \mathrm{~mm} \times 100 \mathrm{~mm} \times 500 \mathrm{~mm}$ were used to find flexural strength. Fig 5.3 shows arrangement of the concrete prism for flexural test.

Flexural strength is calculated using the following formula.

a. When fracture initiates in the tension surface (i.e., the bottom surface) within the middle third of the beam,

$$
M R=\frac{P l}{b d^{2}}
$$


Where $P$ is the failure load, $l$ is the span length, $d$ is the depth of the beam, and $b$ is the width of the beam. All dimensions are in $\mathrm{mm}$.

b. If fracture initiates in the tension surface (i.e., the bottom surface) outside the middle third of the beam by not more than $5 \%$ of the span length.

$$
M R=\frac{3 P a}{b d^{2}}
$$

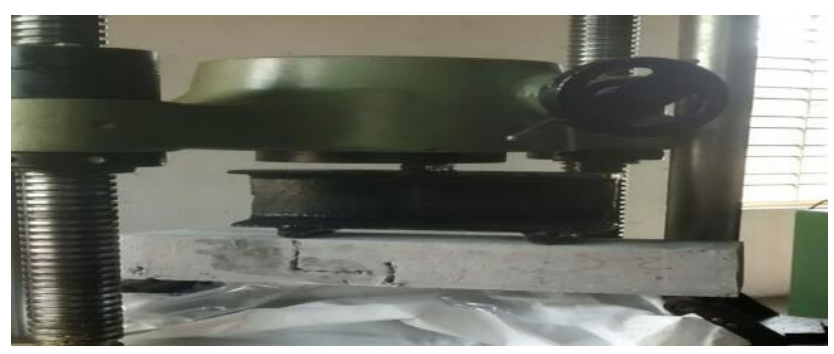

Figure 7. Concrete Prism under flexural test

\section{Modulus of Elasticity}

The modulus of elasticity and poisons ratio of a material are fundamental properties that are needed for modelling mechanical behaviour of structural components and for evaluation of stiffness criteria. For safe and efficient use, the stress - strain response of the composite should be known, with the peak strength and the modulus of elasticity being two of the most important parameters of this response. Thus, there is need to generate experimental data related to the elastic modulus. The modulus of elasticity is determined using the longitudinal Compression meter attached to the specimen. The modulus of elasticity is determined by subjecting the cylindrical specimen to axial compression and measuring the deformation by means of a dial gauge fixed to the longitudinal compression meter at regular intervals. The load on the cylinder is applied at a constant rate up to the failure of the specimen cylinder. Dial gauge reading divided by gauge length will give the strain and load applied divided by area of cross section will give the stress. A series of readings are taken and the stress-strain relationship is developed. A tangent is drawn to the stress strain curve at the origin and the slope of the tangent is taken as initial tangent modulus of elasticity.

\section{RESULTS AND DISCUSSIONS}

Several researchers have investigated the possible use of Bottom Ash \& Quarry Dust as replacement of Fine Aggregate and Polypropylene Fibre as admixture in concrete and its effects on the different mechanical and long-term properties of concrete. Even though there are various research studies have been reported by investigators about Bottom Ash, its physical properties and chemical composition varies country wide and hence its mechanical performance also varies according to that. Therefore, this research was performed to generate specific experimental data on potential use of Bottom Ash replacement and Polypropylene Fibre in concrete.

\section{DISCUSSION OF THE RESULTS}

In this chapter, the results obtained from the concrete specimens of controlled concrete, BA $10 \%$, BA $20 \%$, BA $30 \%$, QD $10 \%$, QD 20\%, QD 30\%, $0.5 \% \mathrm{PF}, 1.0 \% \mathrm{PF}, 1.5 \% \mathrm{PF}$ and the Combined applications are BA 20\%+ QD 30\%+0.5\% PF, BA $20 \%+$ QD $30 \%+1.0 \%$ PF, BA $20 \%+$ QD $30 \%+$ $1.5 \% \mathrm{PF}$.

The composition of above materials was varied to study the effect of optimum level of replacement. Tests were conducted on hardened concrete specimens to obtain the Compressive Strength, Split Tensile Strength, Flexural Strength and Modulus of Elasticity also the Acid Resistance of concrete. Standard procedures were adopted for testing.

\subsection{HARDENED PROPERTIES OF CONCRETE 6.2.1 CUBE COMPRESSIVE STRENGTH OF CONCRETE}

The test results of cube compressive strength of M30 grade concrete with various proportions of Bottom 
Ash (BA), Quarry Dust (QD) and Polypropylene

Fibre $(\mathrm{PF})$ is shown in below Table.

Table 9. Cube Compressive Strengths of M30 Grade of Concrete

\begin{tabular}{|c|c|c|c|c|c|c|c|c|c|}
\hline \multirow{2}{*}{$\begin{array}{c}\text { S. } \\
\text { No }\end{array}$} & Concrete Mix & Bottom & Quarry & Polypropylene & \multicolumn{5}{|c|}{ Compressive Strength (Mpa) } \\
\cline { 7 - 11 } & & $\begin{array}{c}\text { Ash } \\
\text { Dust }\end{array}$ & Fibre (\%) & 3 Days & 7 Days & 28 Days & 56 Days & 90 Days \\
\hline 1 & CC & 0 & 0 & 0 & 18.72 & 27.86 & 41.28 & 42.17 & 43.37 \\
\hline 2 & BA 10\% & 10 & 0 & 0 & 19.75 & 30.35 & 42.61 & 43.01 & 44.08 \\
\hline 3 & BA 20\% & 20 & 0 & 0 & 20.14 & 31.25 & 43.14 & 44.20 & 45.65 \\
\hline 4 & BA 30\% & 30 & 0 & 0 & 19.81 & 30.86 & 43.07 & 43.76 & 44.13 \\
\hline 5 & QD 10\% & 0 & 10 & 0 & 19.21 & 28.63 & 43.37 & 44.25 & 45 \\
\hline 6 & QD 20\% & 0 & 20 & 0 & 19.46 & 30.21 & 43.84 & 45.14 & 46.34 \\
\hline 7 & QD 30\% & 0 & 30 & 0 & 19.92 & 32.24 & 44.01 & 46.05 & 47.65 \\
\hline 8 & PF 0.5\% & 0 & 0 & 0.5 & 18.96 & 28.10 & 41.63 & 42.98 & 43.72 \\
\hline 9 & PF 1.0\% & 0 & 0 & 1.0 & 19.68 & 29.58 & 42.86 & 44.68 & 45.15 \\
\hline 10 & PF 1.5\% & 0 & 0 & 1.5 & 20.56 & 31.07 & 44.26 & 45.17 & 46.8 \\
\hline 11 & BA+QD+PF & 20 & 30 & 0.5 & 20.58 & 33.52 & 45.18 & 47.20 & 48.03 \\
\hline 12 & BA+QD+PF & 20 & 30 & 1.0 & 21.61 & 34.14 & 46.89 & 49.68 & 50.32 \\
\hline 13 & BA+QD+PF & 20 & 30 & 1.5 & 22.34 & 34.76 & 47.65 & 50.29 & 52.16 \\
\hline
\end{tabular}

The cube compressive strength indicates the average of three test results. It can be observed that the compressive strength of concrete prepared by replacing Bottom Ash, Quarry Dust as replacement of Fine Aggregate exhibits improved Compressive Strength individually. With Polypropylene Fibre as admixture exhibits more strength than the control mix. Combined application of Bottom Ash (20\%), Quarry Dust (30\%) \& Polypropylene Fibre (1.5\%) shows $20.27 \%$ improved Compressive Strength compared to Controlled Concrete. The Graphical Representations of the above results are shown below with various Combinations.

From the graphs shown in figure 6.1,The Cube Compressive Strength of Controlled Concrete is compared with various proportions of Bottom Ash (10\%, 20\% \& 30\%), Quarry Dust (10\%, 20\% \& 30\%) and Polypropylene Fibre $(0.5 \%, 1.0 \% \& 1.5 \%)$ and it clearly shows that combined Application of Bottom Ash (20\%), Quarry Dust (30\%) \& Polypropylene
Fibre (1.5\%) exhibits higher Compressive Strength compared to rest of the mixes.

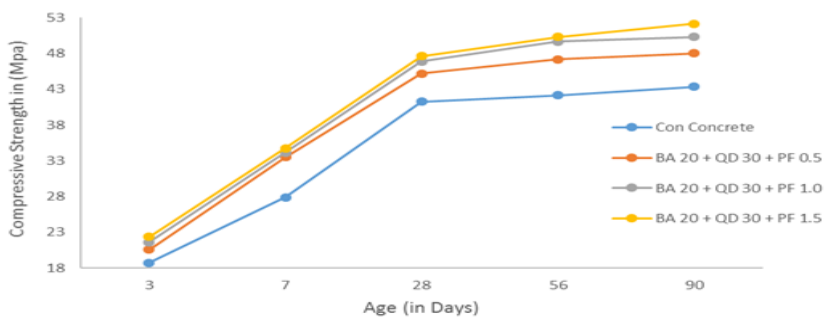

Comparison of Cube compressive strength of Control Concrete with various combinations of Bottom Ash (20\%), Quarry Dust (30\%) \& Polypropylene Fibre $(0.5 \%, 1.0 \% \& 1.5 \%)$

Below Figures shows the variation of 7 - Days and 28 Days Compressive Strength of Concrete with various proportions of Bottom Ash (10\%, 20\% \& 30\%), Quarry Dust (10\%, 20\% \& 30\%) and Polypropylene Fibre $(0.5 \%, 1.0 \% \& 1.5 \%)$ 


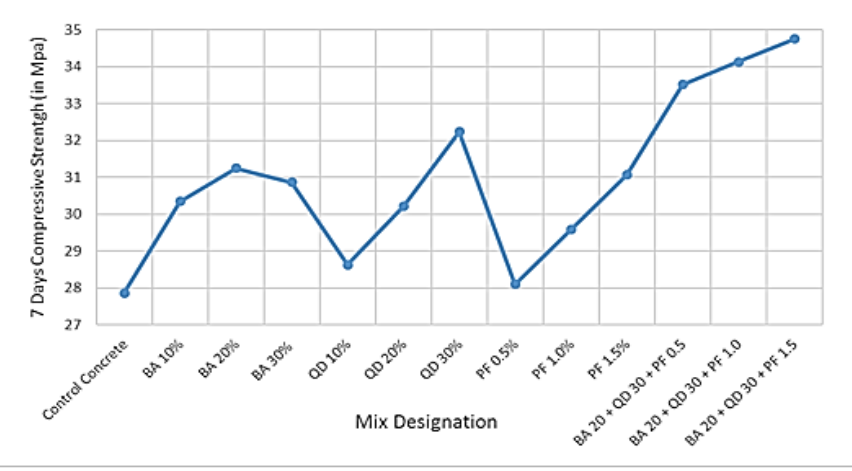

Comparison of 7 - Days Cube compressive strength with various proportions of Bottom Ash (10\%, 20\% \& $30 \%)$, Quarry Dust (10\%, 20\% \& 30\%) and

Polypropylene Fibre $(0.5 \%, 1.0 \%$ \& $1.5 \%)$

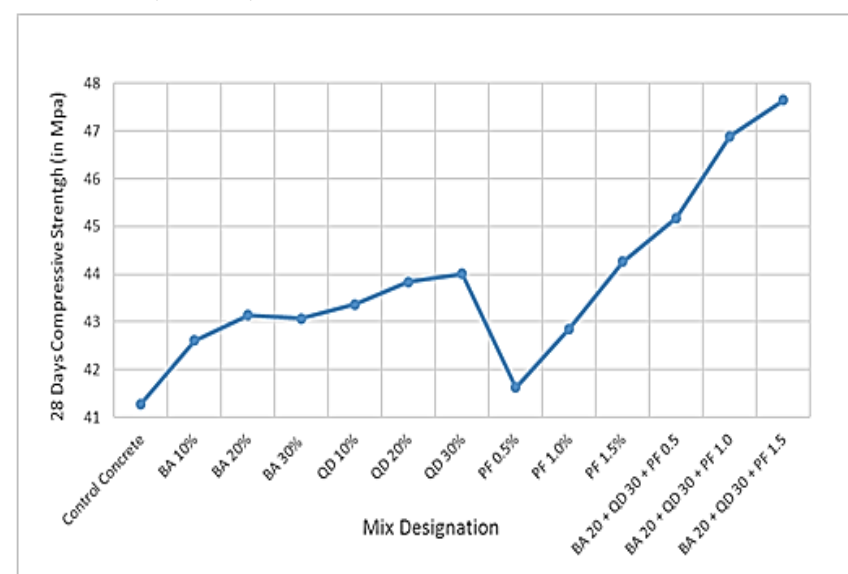

Comparison of 28 - Days Cube compressive strength with various proportions of Bottom Ash (10\%, 20\% \& $30 \%)$, Quarry Dust (10\%, 20\% \& 30\%) and Polypropylene Fibre $(0.5 \%, 1.0 \%$ \& $1.5 \%)$

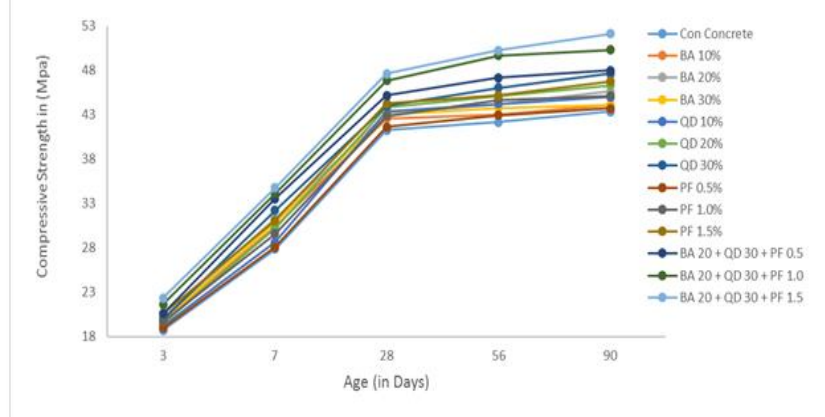

Comparison of 3, 7, 28, 56 \& 90 Days Cube compressive strength with various proportions of Bottom Ash (10\%, 20\% \& 30\%), Quarry Dust (10\%,
$20 \% \& 30 \%)$ and Polypropylene Fibre (0.5\%, 1.0\% \& $1.5 \%)$

Above Figure shows the Comparison of 3, 7, 28, 56 \& 90 Days Cube compressive strength with various proportions of Bottom Ash (10\%, 20\% \& 30\%), Quarry Dust (10\%, 20\% \& 30\%) and Polypropylene Fibre $(0.5 \%, 1.0 \%$ \& $1.5 \%)$. It can be observed that Concrete with Combined application of Bottom Ash (20\%), Quarry Dust (30\%) \& Polypropylene Fibre (1.5\%) shows $20.27 \%$ improved Compressive Strength compared to Controlled Concrete.

\section{SPLIT TENSILE STRENGTH:}

The Test results of Split Tensile Strength of M30 grade concrete with various proportions of Quarry Dust, Bottom Ash and Polypropylene Fibres is shown in Table 6.2.

Table 10. Split Tensile Strength of M30 Grade of Concrete

\begin{tabular}{|c|c|c|c|c|c|}
\hline $\begin{array}{c}\text { S. } \\
\text { N }\end{array}$ & $\begin{array}{c}\text { Concrete } \\
\text { Mix } \\
\text { Designatio } \\
\mathrm{n}\end{array}$ & $\begin{array}{c}\text { Botto } \\
\mathrm{m} \text { Ash } \\
(\%)\end{array}$ & $\begin{array}{c}\text { Quarr } \\
\text { y Dust } \\
(\%)\end{array}$ & $\begin{array}{c}\text { Polypropylen } \\
\text { e Fibre (\%) }\end{array}$ & $\begin{array}{c}\text { Split } \\
\text { Tensile } \\
\text { Strengt } \\
\text { h (in } \\
\text { Mpa) }\end{array}$ \\
\hline 1 & CC & 0 & 0 & 0 & 4.06 \\
\hline 2 & BA 10\% & 10 & 0 & 0 & 4.15 \\
\hline 3 & BA 20\% & 20 & 0 & 0 & 4.18 \\
\hline 4 & BA 30\% & 30 & 0 & 0 & 4.16 \\
\hline 5 & QD 10\% & 0 & 10 & 0 & 4.20 \\
\hline 6 & QD 20\% & 0 & 20 & 0 & 4.23 \\
\hline 7 & QD 30\% & 0 & 30 & 0 & 4.24 \\
\hline 8 & PF 0.5\% & 0 & 0 & 0.5 & 4.08 \\
\hline 9 & PF 1.0\% & 0 & 0 & 1.0 & 4.16 \\
\hline 10 & PF 1.5\% & 0 & 0 & 1.5 & 4.27 \\
\hline 11 & BA 20\% & 20 & 30 & 0.5 & 4.32 \\
+ QD 30\% & & & & \\
\hline & & & & & \\
\hline
\end{tabular}




\begin{tabular}{|c|c|c|c|c|c|}
\hline & + PF0.5\% & & & & \\
\hline 12 & BA 20\% & 20 & 30 & 1.0 & 4.43 \\
& + QD 30\% \\
& + PF1.0\% & & & & \\
\hline 13 & BA 20\% & 20 & 30 & 1.5 & 4.48 \\
& + QD 30\% \\
& & & & \\
\hline
\end{tabular}

From above Table, The Split tensile strength of Control concrete is $4.06 \mathrm{MPa}$.It is observed that all the replacements \& admixtures exhibits improved Strength Characteristics compared to Control Concrete, But the Optimum mix of Bottom Ash (20\%) + Quarry Dust (30\%) + Polypropylene Fibre (1.5\%) resulted in hsignificant improvement with 10.35\% more than Control Concrete. The same is represented Graphically in below Figure

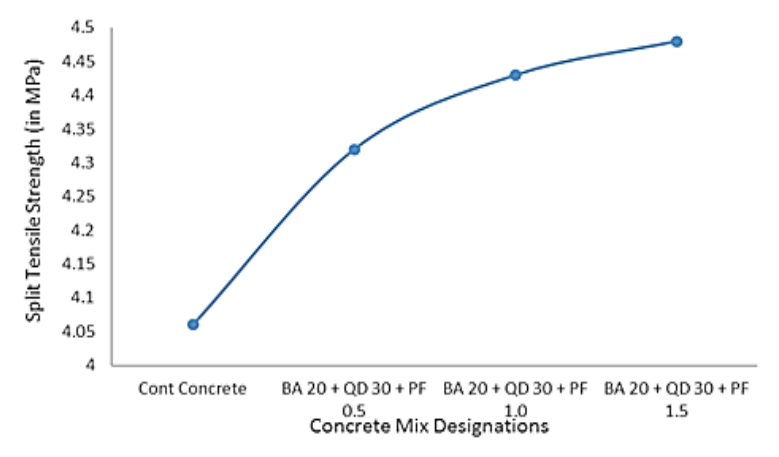

Comparison of Split Tensile strength of Control Concrete with various combinations of Bottom Ash (20\%), Quarry Dust (30\%) \& Polypropylene Fibre $(0.5 \%, 1.0 \% \& 1.5 \%)$

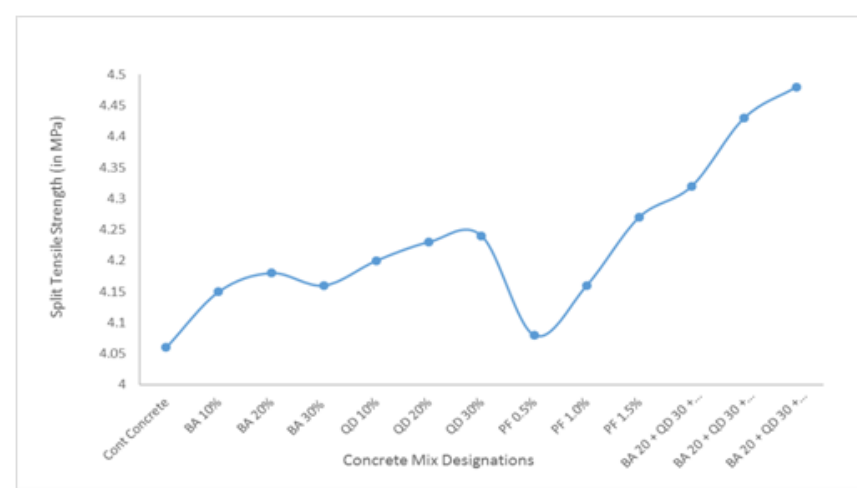

Comparison of Split Tensile strength of Control

Concrete with various proportions of Bottom Ash (10\%, 20\% \& 30\%), Quarry Dust (10\%, 20\% \& 30\%) and Polypropylene Fibre (0.5\%, $1.0 \% \& 1.5 \%)$

\section{FLEXURAL STRENGTH:}

The Test results of Flexural Strength of M30 grade concrete with various proportions of Quarry Dust, Bottom Ash and Polypropylene Fibres is shown in below Table.

Table 11. Flexural Strength of M30 Grade of Concrete

\begin{tabular}{|c|c|c|c|c|c|}
\hline $\begin{array}{l}\text { S. } \\
\text { No }\end{array}$ & $\begin{array}{c}\text { Concrete } \\
\text { Mix } \\
\text { Designation }\end{array}$ & $\begin{array}{l}\text { Bottom } \\
\text { Ash (\%) }\end{array}$ & $\begin{array}{c}\text { Quarry } \\
\text { Dust } \\
(\%)\end{array}$ & $\begin{array}{c}\text { Polypropylene } \\
\text { Fibre (\%) }\end{array}$ & $\begin{array}{l}\text { Flexural } \\
\text { Strength } \\
\text { (in Mpa) }\end{array}$ \\
\hline 1 & $\mathrm{CC}$ & 0 & 0 & 0 & 6.29 \\
\hline 2 & BA 10\% & 10 & 0 & 0 & 6.43 \\
\hline 3 & BA $20 \%$ & 20 & 0 & 0 & 6.49 \\
\hline 4 & BA 30\% & 30 & 0 & 0 & 6.48 \\
\hline 5 & QD 10\% & 0 & 10 & 0 & 6.51 \\
\hline 6 & QD 20\% & 0 & 20 & 0 & 6.56 \\
\hline 7 & QD 30\% & 0 & 30 & 0 & 6.58 \\
\hline 8 & PF 0.5\% & 0 & 0 & 0.5 & 6.33 \\
\hline 9 & PF 1.0\% & 0 & 0 & 1.0 & 6.46 \\
\hline 10 & PF $1.5 \%$ & 0 & 0 & 1.5 & 6.48 \\
\hline 11 & $\begin{array}{l}\text { BA 20\% } \\
+ \text { QD 30\% } \\
+ \text { PF0.5\% }\end{array}$ & 20 & 30 & 0.5 & 6.70 \\
\hline 12 & $\begin{array}{c}\text { BA 20\% } \\
+\mathrm{QD} 30 \% \\
+\mathrm{PF} 1.0 \%\end{array}$ & 20 & 30 & 1.0 & 6.88 \\
\hline 13 & $\begin{array}{l}\text { BA 20\% } \\
+ \text { QD 30\% } \\
+ \text { PF1.5\% }\end{array}$ & 20 & 30 & 1.5 & 6.92 \\
\hline
\end{tabular}

From the above Table, The Flexural strength of Control concrete is recorded as6.29 MPa.It is observed that all the replacements of Fine Aggregates i.e. Bottom Ash (10\%, 20\% \& 30\%), Quarry Dust $(10 \%, 20 \%$ \& 30\%) \& Admixture i.e. (Polypropylene Fibre) individually exhibits improved Flexural Strength Characteristics compared to Control Concrete. It can be noted that combined proportion of Bottom Ash (20\%) + Quarry Dust (30\%) + Polypropylene Fibre (1.5\%) resulted in enormous 
improvement with $10.01 \%$ more than Control Concrete. The same is represented pictorially in below Figure.

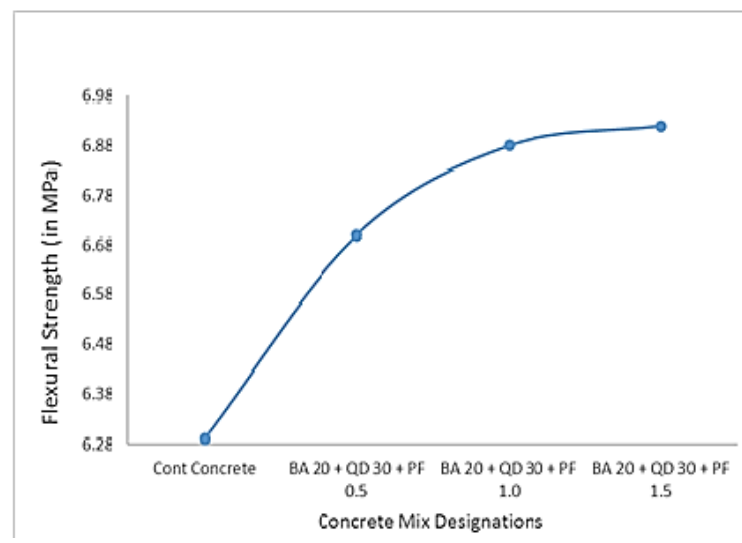

Comparison of Flexural strength of Control Concrete with various combinations of Bottom Ash (20\%), Quarry Dust (30\%) \& Polypropylene Fibre $(0.5 \%$, $1.0 \% \& 1.5 \%)$

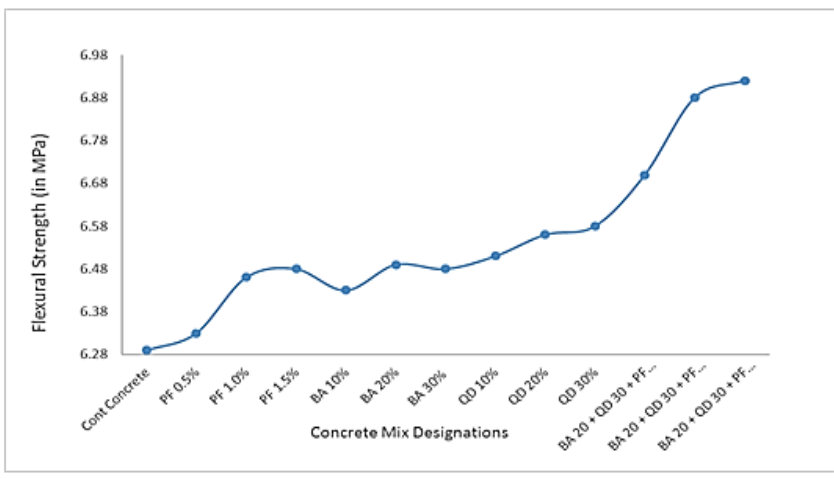

Comparison of Flexural strength of Control

Concrete with various proportions of Bottom Ash (10\%, 20\% \& 30\%), Quarry Dust (10\%, 20\% \& 30\%) and Polypropylene Fibre $(0.5 \%, 1.0 \% \& 1.5 \%)$

\section{MODULUS OF ELASTICITY:}

The Test results of Modulus of Elasticity of M30 grade concrete with various proportions of Quarry Dust, Bottom Ash and Polypropylene Fibres is tabulated in below Table.
Table 12. Modulus of Elasticity of M30 Grade of Concrete

\begin{tabular}{|c|c|c|c|c|c|}
\hline S. No & $\begin{array}{c}\text { Concrete } \\
\text { Mix } \\
\text { Designat } \\
\text { ion }\end{array}$ & $\begin{array}{c}\text { Botto } \\
\text { m } \\
\text { Ash } \\
(\%)\end{array}$ & $\begin{array}{c}\text { Quarry } \\
\text { Dust } \\
(\%)\end{array}$ & $\begin{array}{l}\text { Polyprop } \\
\text { ylene } \\
\text { Fibre (\%) }\end{array}$ & $\begin{array}{c}\text { Modulus Of } \\
\text { Elasticity } \\
(\mathrm{GPa})\end{array}$ \\
\hline 1 & CC & 0 & 0 & 0 & 27.42 \\
\hline 2 & BA $10 \%$ & 10 & 0 & 0 & 27.91 \\
\hline 3 & BA $20 \%$ & 20 & 0 & 0 & 27.98 \\
\hline 4 & BA 30\% & 30 & 0 & 0 & 27.89 \\
\hline 5 & QD 10\% & 0 & 10 & 0 & 28.00 \\
\hline 6 & QD 20\% & 0 & 20 & 0 & 28.17 \\
\hline 7 & QD 30\% & 0 & 30 & 0 & 28.23 \\
\hline 8 & PF $0.5 \%$ & 0 & 0 & 0.5 & 27.42 \\
\hline 9 & PF $1.0 \%$ & 0 & 0 & 1.0 & 27.82 \\
\hline 10 & PF 1.5\% & 0 & 0 & 1.5 & 28.31 \\
\hline 11 & $\begin{array}{c}\text { BA } 20 \% \\
+\mathrm{QD} \\
30 \% \\
+\mathrm{PF} 0.5 \%\end{array}$ & 20 & 30 & 0.5 & 28.63 \\
\hline 12 & $\begin{array}{c}\text { BA } 20 \% \\
+\mathrm{QD} \\
30 \% \\
+\mathrm{PF} 1.0 \%\end{array}$ & 20 & 30 & 1.0 & 29.10 \\
\hline 13 & $\begin{array}{c}\text { BA 20\% } \\
+ \text { QD } \\
30 \% \\
+\mathrm{PF} 1.5 \%\end{array}$ & 20 & 30 & 1.5 & 29.27 \\
\hline
\end{tabular}

From above Table, The Modulus of Elasticity of Control concrete is recorded as27.42 GPa.It is observed that all the replacements of Fine Aggregates i.e. Bottom Ash (10\%, 20\% \& 30\%), Quarry Dust (10\%, 20\% \& 30\%) \& Admixture i.e. (Polypropylene Fibre) individually exhibits improved Flexural Strength Characteristics compared to Control Concrete. It can be noted that combined proportion of Bottom Ash (20\%) + Quarry Dust (30\%) + Polypropylene Fibre (1.5\%) resulted in notable improvement with $6.75 \%$ more than Control 
Concrete. The same is represented pictorially in below Figure.

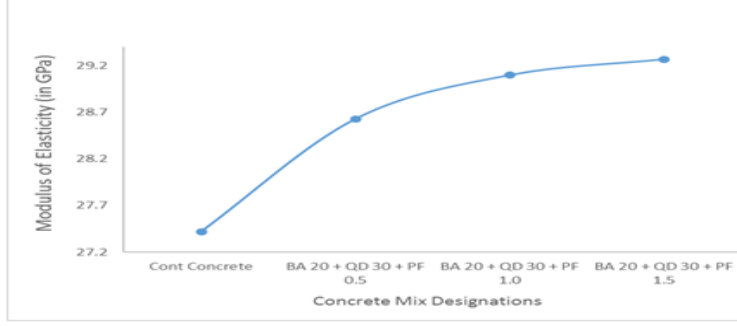

Comparison of Modulus of Elasticity of Control

Concrete with various combinations of Bottom Ash (20\%), Quarry Dust (30\%) \& Polypropylene Fibre $(0.5 \%, 1.0 \% \& 1.5 \%)$

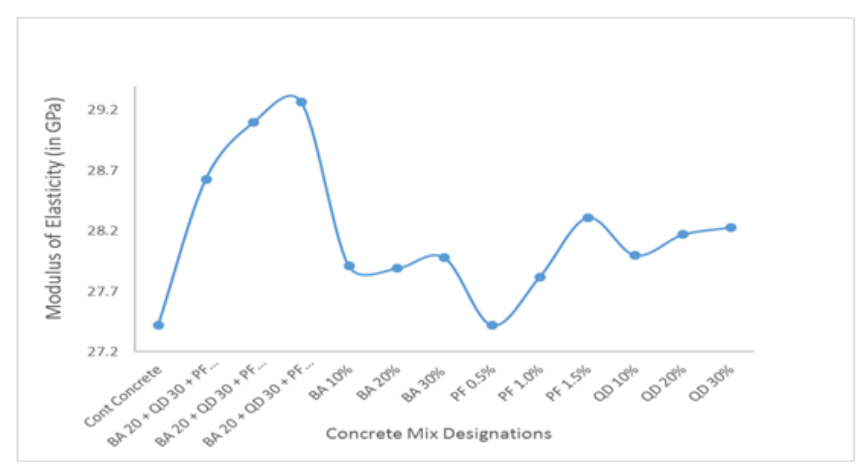

Comparison of Modulus of Elasticity of Control

Concrete with various proportions of Bottom Ash (10\%, 20\% \& 30\%), Quarry Dust (10\%, 20\% \& 30\%) and Polypropylene Fibre (0.5\%, $1.0 \% \& 1.5 \%)$

\section{CONCLUSION}

In this research work, the effect of low-calcium Coal Bottom Ash\& Quarry Dust as partial replacement of sand properties of fresh concrete and Polypropylene Fibre as admixture, Strength and Durability properties of concrete has been studied.The properties of concrete studied include Compressive Strength, Splitting Tensile Strength, Flexural Strength, and Modulus of Elasticity.

Test results indicate that low-calcium Coal Bottom Ash\& Quarry Dust is a suitable material to be used as fine aggregates in partial replacement of river sand in production of concrete. Based on the analysis of test results and discussion following conclusions can be drawn.

\section{PROPERTIESOF FRESH CONCRETE}

In addition to properties such as workability and water loss through bleeding, air content in fresh concrete incorporating low-calcium Coal Bottom Ash\& Quarry Dust which has not been reported so far, has been studied in this work

\section{STRENGTH PROPERTIES OF HARDENED CONCRETE}

In addition to Compressive Strength, Splitting Tensile Strength, Modulus of Elasticity which have been reported in the literature, the strength properties such as Flexure strength of concrete incorporating Coal Bottom Ash\& Quarry Dust as replacement of fine aggregate and Polypropylene Fibre as an admixture which have not been reported so far, have been studied in this research work.

\section{Compressive Strength}

It is observed that the compressive strength of concrete prepared by replacing Bottom Ash, Quarry Dust as replacement of Fine Aggregate exhibits improved Compressive Strength individually. With Polypropylene Fibre as admixture exhibits more strength than the control mix. Combined application of Bottom Ash (20\%), Quarry Dust (30\%) \& Polypropylene Fibre (1.5\%) shows 20.27\% improved Compressive Strength compared to Controlled Concrete

\section{Split Tensile Strength}

The Split tensile strength of Control concrete is 4.06 MPa.It is observed that all the replacements \& admixtures exhibits improved Strength Characteristics compared to Control Concrete, But the Optimum mix of Bottom Ash (20\%) + Quarry Dust (30\%) + Polypropylene Fibre (1.5\%) resulted in significant improvement with $10.35 \%$ more than Control Concrete. 


\section{FlexuralStrength}

The Flexural strength of Control concrete is recorded as $6.29 \mathrm{MPa}$. It is observed that all the replacements of Fine Aggregates i.e. Bottom Ash (10\%, 20\% \& $30 \%)$, Quarry Dust (10\%, 20\% \& 30\%) \& Admixture i.e. (Polypropylene Fibre) individually exhibits improved Flexural Strength Characteristics compared to Control Concrete. It can be noted that combined proportion of Bottom Ash (20\%) + Quarry Dust $(30 \%)+$ Polypropylene Fibre $(1.5 \%)$ resulted in enormous improvement with $10.01 \%$ more than Control Concrete.

\section{Modulus of Elasticity}

The Modulus of Elasticity of Control concrete is recorded as $27.42 \mathrm{GPa}$. It is observed that all the replacements of Fine Aggregates i.e. Bottom Ash (10\%, 20\% \& 30\%), Quarry Dust (10\%, 20\% \& 30\%) \& Admixture i.e. (Polypropylene Fibre) individually exhibits improved Flexural Strength Characteristics compared to Control Concrete. It can be noted that combined proportion of Bottom Ash (20\%) + Quarry Dust $(30 \%)+$ Polypropylene Fibre (1.5\%) resulted in notable improvement with $6.75 \%$ more than Control Concrete.

\section{Further Research}

The inclusion of coal Bottom Ash \& Quarry Dust as fine aggregate decreases an early age compressive strength of concrete. As such, further research to explore the possible ways to enhance the early age strength of Bottom Ash concrete is needed.

Cite this article as :

\section{REFERENCES}

[1]. Abdelaty, M. a. a., (2014). "Compressive strength prediction of Portland cement concrete with age using a new model." Housing and Building National Research Center(HBRC) Journal; 10: 145-155

[2]. Aggarwal P., Aggarwal Y. and Gupta S.M. (2007), "Effect of bottom ash as replacement offine aggregates in concrete.” Asian Journal of Civil Engineering (Building andHousing); 8: 4962

[3]. Al-Amoudi, O.S.B., Al-Kutti, W. A., Ahmad, S. and Maslehuddin, M., (2009)."Correlation between compressive strength and certain durability indices of plain andblended cement concretes" Cement \& Concrete Composites; 31: 672-676

[4]. American Coal Ash Association (ACAA). 2006 coal combustion product (CCP)production and use. Aurora, CO: American Coal Ash Association; 2007.

[5]. Andrade L.B., RockaJ.C.andCheriaf M. (2007), "Aspects of moisture kinetics of coalbottom ash in concrete." Cement and Concrete Research; 37: 231-241

[6]. Behim M., Cyr M., and Clastres P., (2011), "Physical and chemical effects of El Hadjarslag used as an additive in cement-based materials." European Journal ofEnvironmental and Civil Engineering; 15(10): 1413-32

[7]. Brown PW. (1981), "An evaluation of the sulphate resistance of cements in a controlledenvironment." Cement and Concrete Research; 11:719-27.239

[8]. Cachim P., Velosa AL, and Ferraz E. (2014), "Substitution Materials for sustainableconcrete production in Portugal." KSCE Journal of Civil Engineering; 18(1): 60-66

[9]. Cachim, P. B. (2009), "Mechanical properties of brick aggregate concrete." Constructionand Building Materials; 23 (3): 1292-1297.

[10]. CharkradharaRao M., Bhattacharyya S. K. and Barai S. V. (2011), "Behaviour ofrecycled aggregate concrete under drop weight impact load." Construction andBuilding Material; 25(1): 69-80 
[11]. Cheriaf M., Rocka J.C. and Pera J. (1999), "Pozzolanic properties of pulverized coalcombustion bottom ash." Cement and Concrete Research, 29:1387-1391

[12]. Chun L.B., Sung K. J., Sang K. T. and Chae S.T. (2008), "A study on the fundamentalproperties of concrete incorporating pond-ash in Korea." The 3rd ACF InternationalConferenceACF/VCA, 401-408

[13]. Cwrizen A., Penttala V. and Vornanen C. (2008), "Reactive powder based concretes:Mechanical properties, durability and hybrid use with OPC." Cement and concreteResearch; 38:1217-26

[14]. Cyr M., Aubert JE., Husson B., and Clastres P. (2006), "Management of mineral wastes in cement- based materials." Revue Europeenne de Genie Civil, 10(3):323-37

[15]. Evangelista L and Brito JD, (2007), "Mechanical behaviour of concrete made with finerecycled aggregate." Cement and Concrete Research; 29:397-401

[16]. Figueiredo C. P., Santos F. B., Cascudo O., Carasek H., Cachim P. and Velosa A. (2014), "The role of metakaolin in the protection of concrete against the deleterious action of chlorides." IBRACON Structures and Materials Journal; 7(4): 685-708

[17]. Fernandez-Turiel J.L., Georgakopoulos A., Gimeno D., Papastergios G. and Kolovos N.(2004), "Ash Deposition in a Pulverized CoalFired Power Plant after High-CalciumLignite Combustion." Energy and Fuels; 18:1512-1518

[18]. Folagbade, Samuel Olufemi (2012), "Effect of fly ash and silica fume on the sorptivityofconcrete." International Journal of Engineering Science and Technology (IJEST);4(9):4238-46

[19]. Folagbade, Samuel Olufemi (2012), "Sorptivity of Cement Combination ConcretesContaining Portland Cement, Fly Ash AndMetakaolin."
International Journal ofEngineering Research and Applications (IJERA); 2(5):1953-59

[20]. Ghafoori N. and Bucholc J. (1996), "Investigation of Lignite Based Bottom Ash forStructural concrete." Journal of Materials in Civil Engineering; 8(3):128-137

[21]. Ghafoori N. and Bucholc J. (1997), "Properties of High-Calcium Dry Bottom Ashconcrete." ACI Materials Journal; 94(2): 90-101

\section{Cite this article as :}

